\title{
PEMANFAATAN LIMBAH BANDENG CABUT DURI (TANDU) KHAS KENDAL SEBAGAI ALTERNATIF BAHAN MAKANAN
}

\author{
${ }^{1}$ Agung Setyo Sasongko*, ${ }^{2}$ Kulistyowati \\ ${ }^{1}$ Magister IImu kelautan-UNDIP, ${ }^{2}$ Magister Manajemen Sumber Daya Pantai-UNDIP \\ Tembalang, Semarang JAWA TENGAH \\ agungsetyosasongko@yahoo.co.id
}

\begin{abstract}
ABSTRAK
Bandeng merupakan salah satu sumber pangan yang sangat bergizi. Akan tetapi, konsumsi masyarakat terhadap Bandeng kurang karena mempunyai tulang dan duri yang cukup banyak sehingga berisiko tinggi bila dikonsumsi oleh manusia terutama anak-anak. Diversifikasi olahan produk Bandeng merupakan salah satu upaya untuk memenuhi selera masyarakat dalam mengkonsumsi ikan sebagai sumber protein, yang juga merangsang berkembangnya budidaya Bandeng. Salah satu upaya diversifikasi Bandeng yaitu dengan cara mencabut durinya. Kabupaten Kendal adalah salah satu kabupaten yang mempunyai banyak pengolah cabut duri Bandeng.

Limbah kegiatan cabut duri di Kabupaten Kendal yang selama ini hanya dimanfaatkan sebagai bahan tambahan pakan ikan atau ternak dirasakan kurang bermanfaat. Dengan kandungan protein sebesar (20.38\%), Bandeng merupakan salah satu sumber pangan yang sangat bergizi. Oleh karena itu, masyarakat terutama pengolah Bandeng Cabut Duri memanfaatkan limbah hasil cabut duri menjadi berbagai macam olahan makanan.

Makalah ini mengangkat tentang pamanfaatan limbah duri yang dihasilkan dari proses cabut duri Bandeng.Tujuan dari makalah ini adalah untuk mengetahui upaya masyarakat khususnya pengolah Bandeng Cabut Duri dalam memanfaatkan limbah durinya.
\end{abstract}

Kata Kunci : Duri, Bandeng, Olahan

\section{PENDAHULUAN}

Jenis olahan bandeng yang ada saat ini cenderung menjadi bahan makanan kuno yang tingkat konsumsinya sangat rendah pada strata konsumen biasa, sedangkan kecenderungan masyarakat sekarang ini berpola konsumsi yang bersifat instan sekalipun pada golongan menengah ke bawah. Pengolahan bandeng tanpa duri merupakan upaya untuk meningkatkan konsumsi ikan bandeng bagi konsumen (Vatria, 2010).

Olahan dari Bandeng selama ini hanya dengan cara presto yaitu memasak Bandeng pada suhu tinggi sehingga duri yang ada bisa menjadi lunak. Tetapi kemungkinan dengan cara memasak pada suhu tinggi akan mengurangi kandungan yang ada pada bandeng. Selain itu juga akan menimbulkan bosan pada masyarakat karena hanya presto saja olahan dari Bandeng selama ini. Padahal Bandeng adalah komoditas yang mudah didapat dan selalu ada setiap saat (Ditjen PK2P,2003). 
Oleh karena itu akhir-akhir ini di Kabupaten Kendal sedang dikembangkan usaha pengolahan bandeng cabut duri atau yang biasa disebut Bandeng tanpa duri. Kelebihan dari Bandeng Tanpa Duri ini yaitu tidak mengurangi atau menghilangkan kandungan gizi yang terdapat pada Bandeng mentah, karena pengolahannya hanya menghilangkan duri yang ada pada Bandeng, bukan memasaknya. Bandeng Tanpa Duri ini selanjutnya dapat dimanfaatkan menjadi berbagai variasi makanan sesuai dengan selera. Beberapa produk olahan dari Bandeng Tanpa Duri ini antara lain Bandeng Pepes, Bandeng Asap, Bandeng Nugget, Bandeng Fillet dan sebagainya, akan tetapi limbah yang dihasilkan dari produksi tersebut ialah duri dari ikan Bandeng tidak termanfaatkan secara optimal,oleh karenanya perlu inovasi untuk membuat olahan makanan dari duri ikan Bandeng (Sasongko dan Kulistyowati, 2012)

\section{TINJAUAN UMUM BANDENG}

Ikan bandeng merupakan salah satu ikan konsumsi yang hidupnya tersebar didaerah tropis Indo Pasifik dan daerah penyebarannya di Asia diantaranya Indonesia. Indonesia merupakan daerah penyebaran bandeng yang telah diketahui meliputi perairan pantai timur Sumatera, utara Jawa, Kalimantan, Sulawesi, Maluku, Papua, Bali dan Nusa Tenggara, Disamping itu bandeng juga telah menjadi komoditas yang memiliki tingkat konsumsi yang tinggi terutama di daerah Jawa dan Sulawesi Selatan, sehingga meningkatkan kontribusi cukup besar bagi peningkatan gizi masyarakat (Ditjen PK2P,2003).

Ikan Bandeng (Latin: Chanos chanos atau Inggris: Milkfish) merupakan salah satu jenis ikan yang memiliki rasa yang spesifik, dan telah dikenal masyarakat. Dengan kandungan protein yang tinggi (20.38\%), Bandeng merupakan salah satu sumber pangan yang sangat bergizi. Adanya diversifikasi olahan produk Bandeng merupakan salah satu upaya untuk memenuhi selera masyarakat dalam mengkonsumsi ikan sebagai sumber protein, yang juga merangsang berkembangnya budidaya Bandeng. Akan tetapi, kelemahan dari Bandeng ini yaitu adanya tulang dan duri yang cukup banyak di dalam tubuhnya sehingga berisiko tinggi bila dikonsumsi oleh manusia terutama anak-anak. Hal ini mengurangi minat masyarakat untuk mengkonsumsi Bandeng. Jumlah duri yang terdapat pada Bandeng adalah sebagai berikut; pada bagian punggung ada 42 pasang duri bercabang yang menempel di dalam daging dekat permukaan kulit luar, bagian tengah ada 12 pasang duri pendek, pada rongga perut ada 16 duri pendek dan bagian perut dekat ekor ada 12 pasang duri (Direktorat Kredit, BPR dan UMKM Biro Pengembangan UMKM, 2008). 


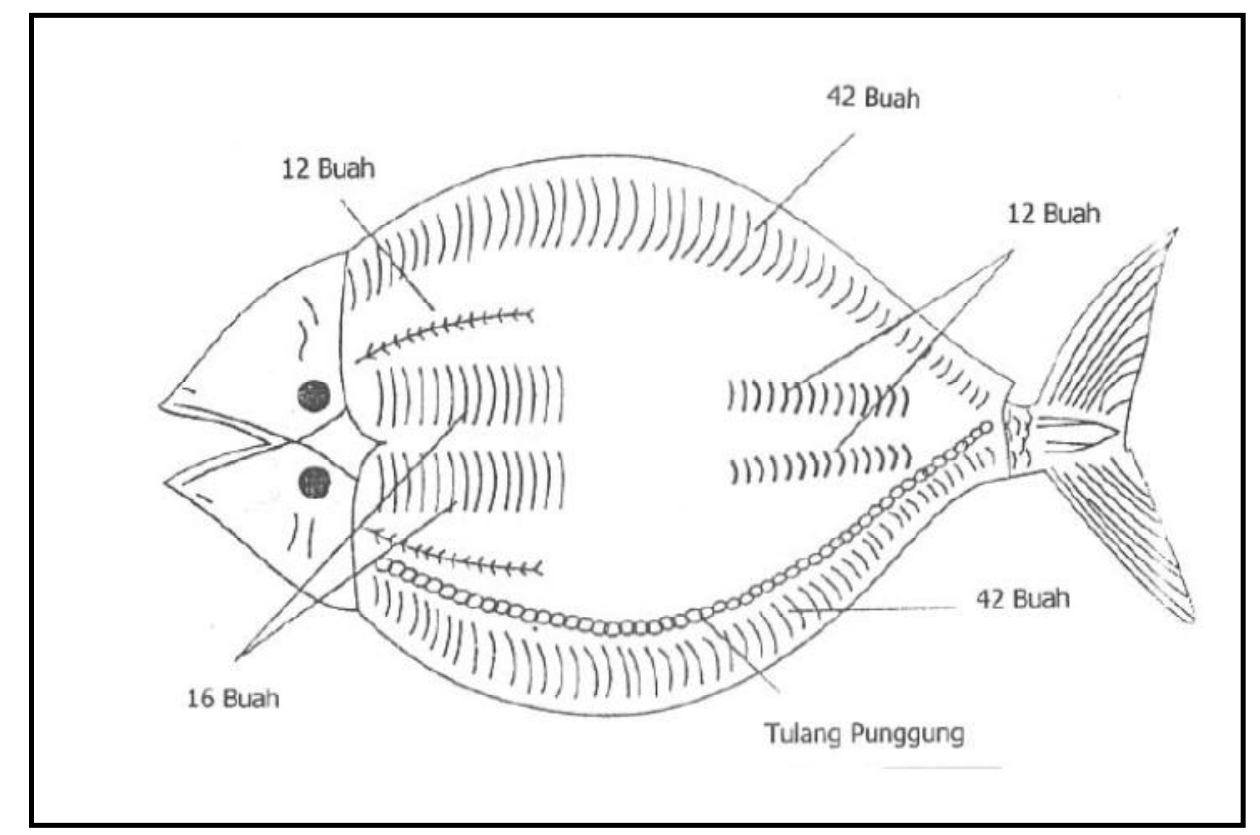

Gambar 1. Struktur Duri Pada Bandeng (Direktorat Kredit, BPR dan UMKM Biro Pengembangan UMKM, 2008).

\section{BAHAN DAN METODE}

3.1. Bahan - Bahan yang digunakan

Dalam Pembuatan Olahan makanan dari Duri Ikan Bandeng dibutuhkan bahan sebagai berikut :

1. Duri Ikan Bandeng

2. Tepung Beras

3. Daun Jeruk Purut

4. Air

5. Minyak Goreng

6. Telur
6. Bumbu Masakan Meliputi :

- Garam

- Gula

- Cabai

- Bawang Putih

- Ketumbar

- Kemiri

- Kapur sirih

(Sasongko dan Kulistyowati, 2012)

\subsection{Alat - alat yang digunakan}

Dalam proses pembuatan olahan bahan duri ada beberapa alat yang digunakan antara lain :

1. Presto

6. Kompor

2. Baskom

7. Telenan

3. Wajan

8. Sendok

4. Pisau

5. Blender

(Sasongko dan Kulistyowati, 2012) 


\subsection{Alur skema Pengolahan Duri Ikan Bandeng}

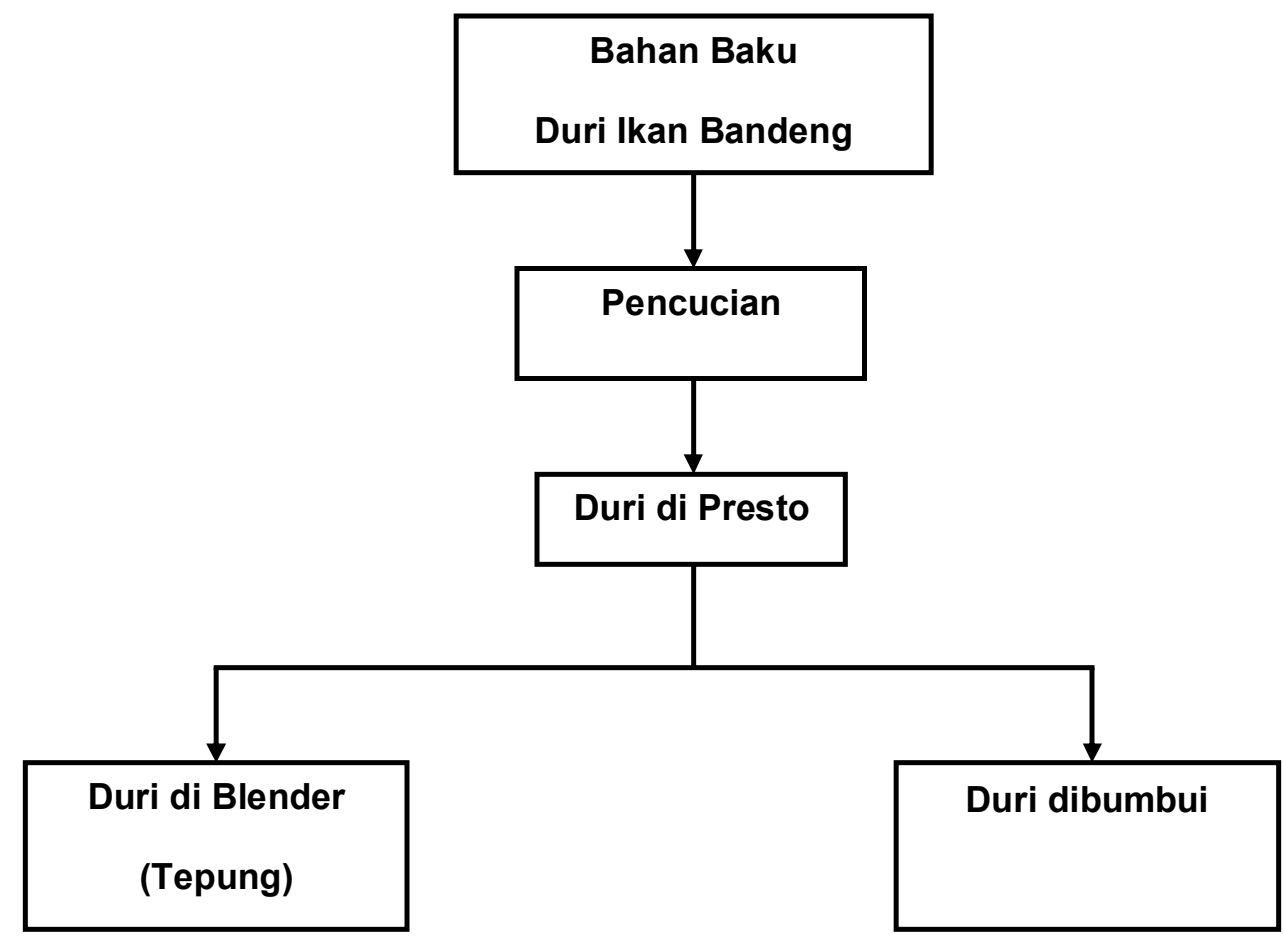

Gambar 2. Proses pengolahan Duri Ikan Bandeng (Sasongko dan Kulistyowati, 2012)

\section{HASIL DAN PEMBAHASAN}

\subsection{Diversifikasi Produk}

Dari hasil duri yang di presto dihasilkan bahan setengah jadi diantaranya :

1. Duri di Blender (Tepung) bisa dijadikan olahan sebagai berikut :

- Putu tulang Bandeng

- Jahe Manis Tulang Bandeng

- Nugget tulang Bandeng

- Kerupuk

2. Duri dibumbui

- Tumpi

- Abon

\subsection{Respon Konsumen terhadap Produk Olahan dari Duri Bandeng}

Selama ini duri bandeng dimanfaatkan sebagai bahan tambahan pakan ternak, melihat tingginya kandungan gizi yang terdapat dalam duri, tercetus ide untuk memanfaatkan menjadi produk makanan. cara pengolah dalam memanfaatkan duri dengan cara membuat tepung yang dicampurkan ke adonan, dari tepung bisa dibuat menjadi olahan 
makanan berbahan dasar duri. selain dihancurkan menjadi tepung ada yang berupa duri kasar dibuat menjadi tumpi dan abon.

Respon masyarakat terhadap produk olahan duri sangat baik dan antusias, produk berbahan dasar duri sudah diperjualbelikan di toko oleh-oleh sekitar Kendal dan Semarang.

\section{KESIMPULAN}

Salah satu jenis ikan yang banyak mengandung duri adalah ikan bandeng,banyak cara untuk menghilangkan cara durinya yaitu dicabut durinya,akan tetapi limbah yang dihasilkan bisa dimanfaatkan sebagai olahan makanan atau cemilan yang enak sekaligus bergizi

Duri adalah Salah satu inovasi produk olahan diseversifikasi hasil perikanan. Tahapan pengolahan ikan bandeng tanpa duri adalah : penerimaan bahan baku, pencucian, Duri di presto, Duri setengah Matang, Pemasakan, pengemasan.

\section{DAFTAR PUSTAKA}

Direktorat Jenderal PK2P, 2003. Statistik Perikanan Indonesia. Jakarta; Departemen Kelautan dan Perikanan.

Direktorat Kredit, BPR dan UMKM Biro Pengembangan UMKM, 2008. Pola pembiayaan Usaha Kecil Bandeng Tanpa Duri. Jakarta; Departemen Kelautan dan Perikanan dan Bank Indonesia.

Vatria Belvi, 2010. Pengolahan Ikan Bandeng (Chanos-Chanos ) Tanpa Duri. Jurnal IImu Pengetahuan dan Rekayasa Edisi Januari 2010.

\section{TERIMA KASIH}

Bandeng Kendal, Dinas Kelautan dan Perikanan Kabupaten Kendal, Magister IImu Kelautan-UNDIP,Magister Manajemen Sumber Daya Pantai-UNDIP, Beasiswa Unggulan. 


\section{LAMPIRAN GAMBAR}

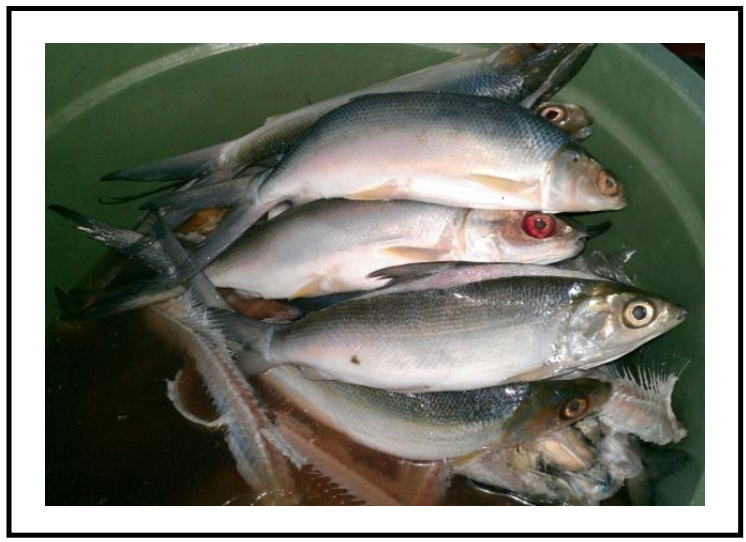

Gambar 1. Penyiangan Bandeng

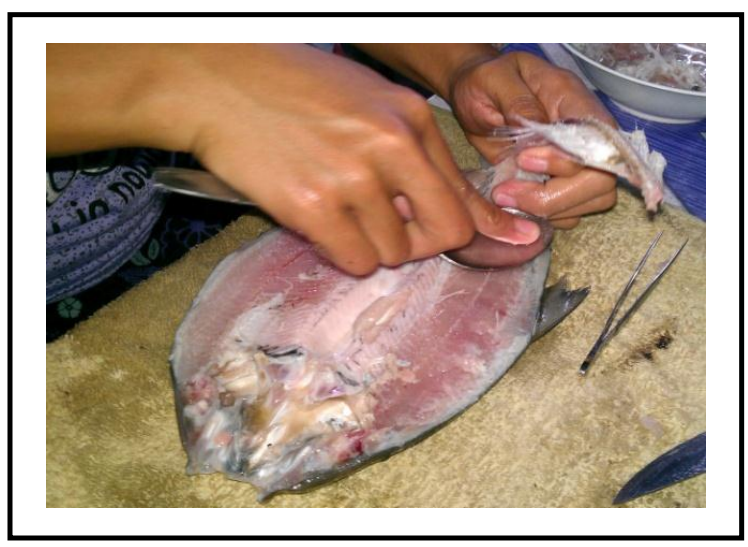

Gambar 3. Pembersihan Duri tulang punggung

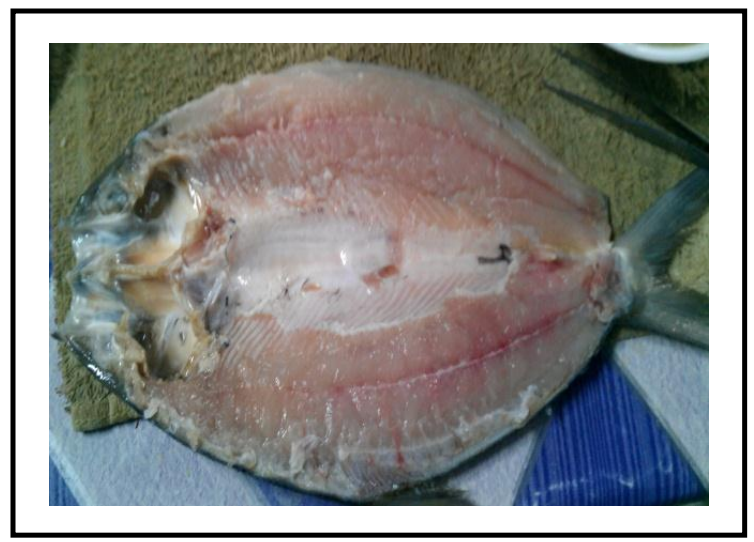

Gambar 5. Bandeng yang bersih dari duri

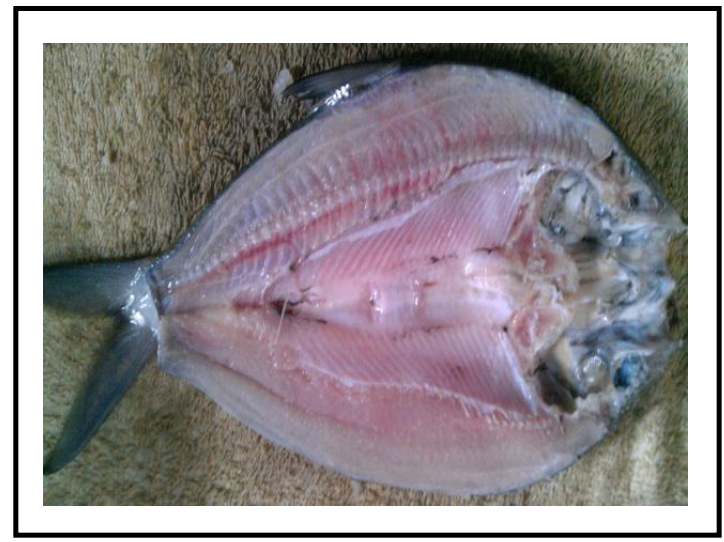

Gambar 2. Duri Bandeng siap cabut

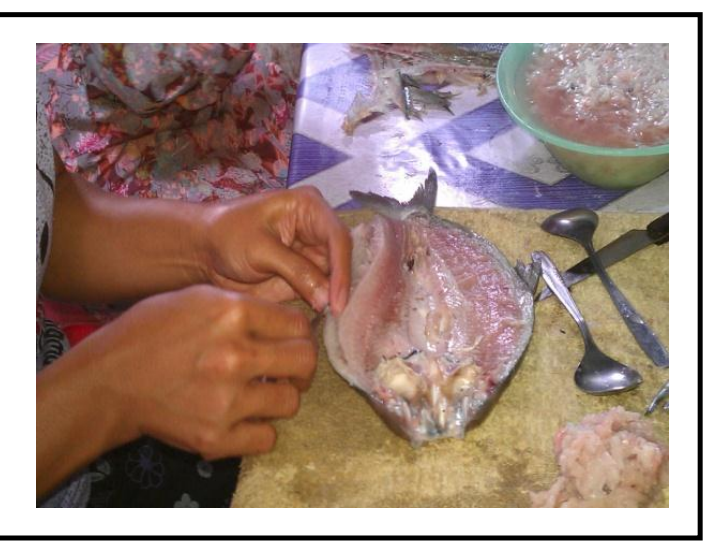

Gambar 4. Pembersihan Duri Halus

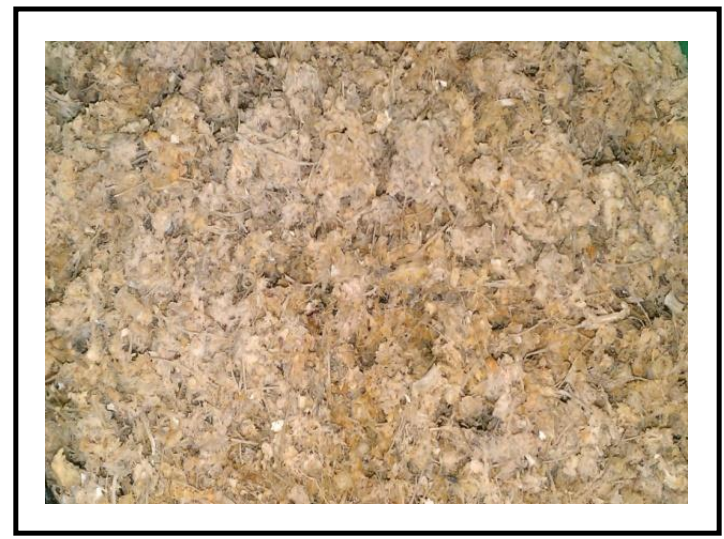

Gambar 6. Duri yang sudah di Presto 


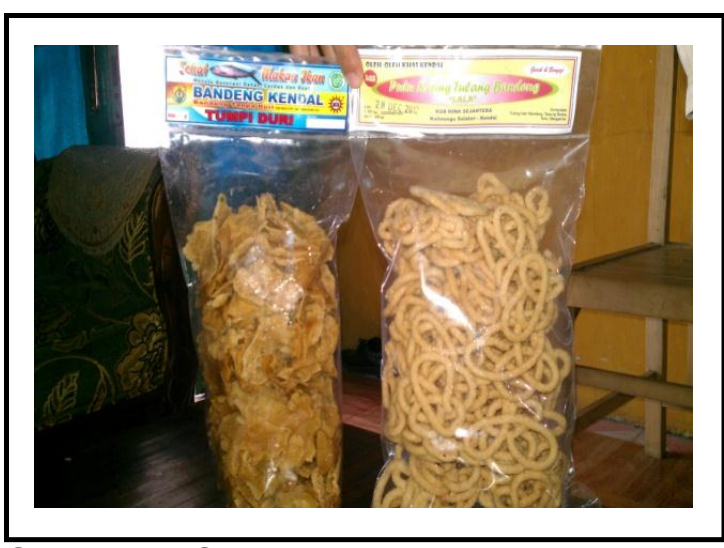

Gambar 7. Olahan dari Duri Bandeng

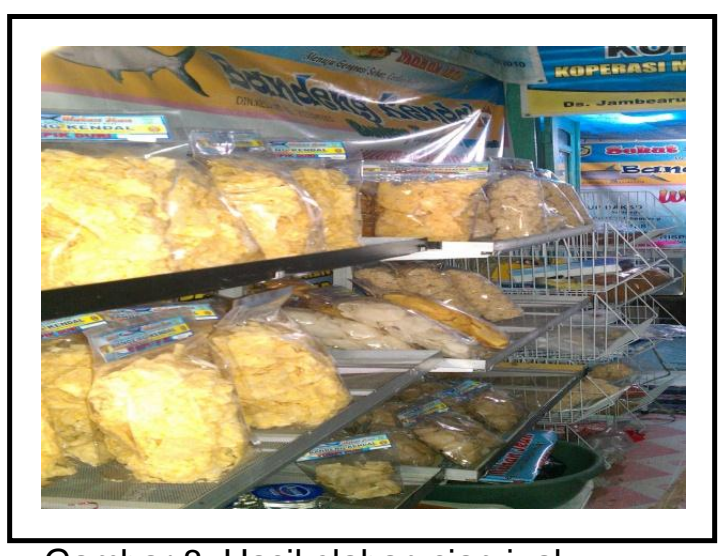

Gambar 8. Hasil olahan siap jual 